"Determinants of strategy disclosure quality: empirical evidence from Germany"

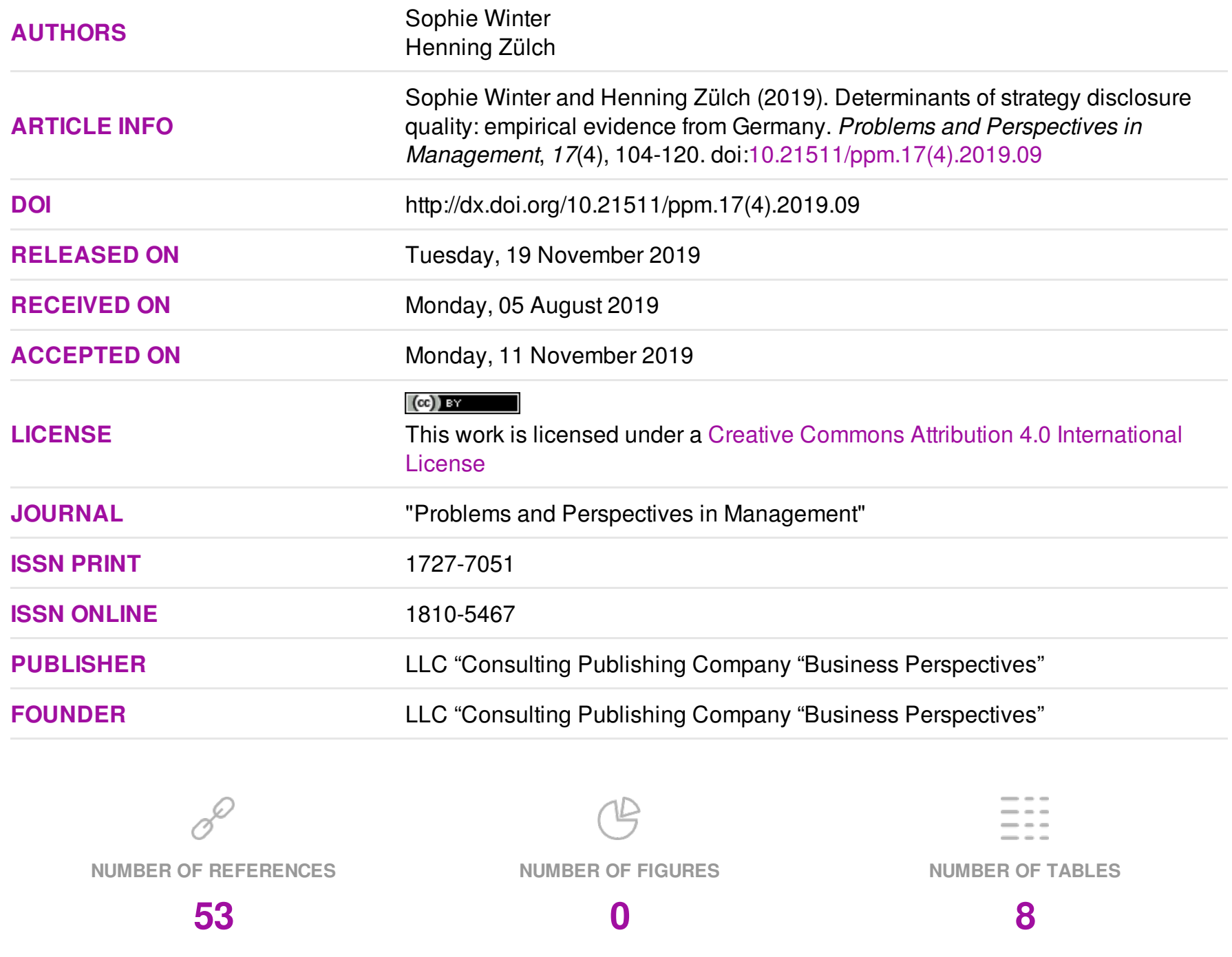

(c) The author(s) 2023. This publication is an open access article. 


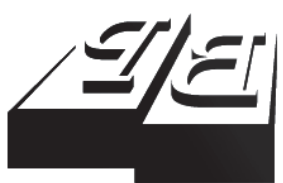

BUSINESS PERSPECTIVES

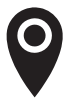

LLC "CPC "Business Perspectives" Hryhorii Skovoroda lane, 10, Sumy, 40022, Ukraine

www.businessperspectives.org

Received on: $5^{\text {th }}$ of August, 2019 Accepted on: $11^{\text {th }}$ of November, 2019

(c) Sophie Winter,

Henning Zülch, 2019

Sophie Winter, Research Associate, Chair of Accounting and Auditing, HHL Leipzig Graduate School of Management, Germany.

Henning Zülch, Professor, Chair of Accounting and Auditing, HHL Leipzig Graduate School of Management, Germany.

\section{DETERMINANTS OF STRATEGY DISCLOSURE QUALITY: EMPIRICAL EVIDENCE FROM GERMANY}

\begin{abstract}
Strategy reporting is of high interest to investors and can be seen as decision-useful information. The focus of this study is to analyze the determinants of the quality of voluntary strategy disclosure in German management reports of capital market-oriented companies. Based on a theoretical analysis, hypotheses are formulated to investigate the determinants of the quality of voluntary strategy disclosure. In order to test the hypotheses, a number of statistical tests are performed, especially multiple regression analyses. It is based on a unique hand-collected dataset with a self-constructed scoring model, which measures the quality of voluntary strategy disclosure. The sample comprises 110 largest companies in Germany for the period between 2014 and 2018. The results indicate that firm size, firm growth and capital intensity determine voluntary strategy disclosure significantly and positively. Conversely, firm age, financial leverage, ownership structure and profitability do not have a significant relationship with voluntary strategy disclosure. The results are robust to different statistical analysis. This research provides insights into a neglected topic in academia and helps decision-makers in practice and regulators to better understand voluntary strategy disclosure of capital market-oriented companies.
\end{abstract}

\section{Keywords}

\section{JEL Classification}

determinants, voluntary strategy disclosure, disclosure quality, management report

\section{INTRODUCTION}

A clear and focused strategy is vitally important, especially for capital market-oriented companies because they are of high public interest (Porter, 1980, 1997). Investors and other addressees of corporate reporting have a decision-making perspective and need insights into a firms' business strategy to understand long-term managerial actions. Nevertheless, voluntary strategy reporting is a widely neglected topic in academic research as well as in management practice, even though the strategy of a company can be a decisive factor for companies to be successful in the future. Therefore, the quality of strategy disclosure and the correspondingly relevant determinants are of high interest to the stakeholders of a company. In a first step, this study measures the quality of voluntary strategy disclosure. In a second step, the impact of various company specific determinants on voluntary strategy disclosure in management reports of German capital market-oriented companies is analyzed. We test this by relating voluntary strategy disclosure level to firm size, firm age, firm growth, capital intensity, financial leverage, profitability and ownership structure. We construct a scoring model for the measurement of the quality of strategy disclosure and formulate a company-specific Strategy Disclosure Score (SDScore). The total firm-year observations are 417, based on a sample, which comprises 110 largest capital market-oriented companies in Germany between 2014 and 2018. Focusing on the management report accord- 
ing to German accounting regulation (par. 264(1), 315a HGB), voluntary strategy disclosure is analyzed in this study. As disclosure of strategy relevant information is on a voluntary basis, this study considers regulations on voluntary strategy disclosure according to German Accounting Standard (GAS) 20. The management report is a reporting platform for companies, where firms have to provide prospective information, which is why this part of the annual report is of particular interest to investors. Due to the fact that the management report is under audit obligation, the analyzed information about the firm's strategy has a high credibility because of the third-party validation.

This empirical study belongs to the research field of voluntary disclosure in financial reporting. Whereas some studies focus on determinants of voluntary disclosure (D’Amico, Coluccia, Fontana, \& Solimene, 2016; Hashim, Nawawi, \& Salin, 2014), determinants of voluntary strategy disclosure are rather rarely analyzed. Hence, this study extends the existing literature on voluntary disclosure and analyzes relevant determinants on voluntary disclosure related to corporate strategy. Since this study is based on regulatory requirements, which have not been analyzed before, the findings are a valuable contribution to the ongoing discussion on voluntary strategy disclosure, which is a neglected topic in academia and of high interest for practitioners. Furthermore, the used scoring-model evaluates all criteria based on the individual strategy of a company and is unique compared to other measurement tools used in research before.

This study is structured as follows. In section 1, we discuss the theoretical understanding for the empirical model, which is grounded in stakeholder and agency theory. We review the literature on similar studies focusing on determinants of disclosure scores and on related research questions. In section 2 , we formulate the research question and derive hypotheses based on the theories. In section 3 , the methodology of the empirical estimation model is explained and the sample selection and characteristics are shown. In section 4, we present and discuss the results of the descriptive statistics, the bivariate statistical models as well as of the multiple regression analysis. Finally, last section concludes with a discussion of the empirical findings and further research questions. In this section, limitations of the statistical method are presented accompanied by a short summary.

\section{LITERATURE REVIEW AND HYPOTHESES DEVELOPMENT}

Business literature and research on corporate strategy find various arguments why strategy communication is relevant. This study focuses on the factors influencing a strategy communication process and especially analysis the determinants of strategy disclosure. Stakeholder theory and agency theory include elements, which give such reasons and can be used to explain enhanced disclosure or a reduction of information about corporate strategy. Empirical research explains how voluntary disclosure and disclosure of prospective information helps to reduce agency conflicts (Hossain et al., 2005). Agency theory focuses on conflicts of interests between principals and agents and is especially important in the context of reducing information asymmetries between them. Based on agency theory, which was mainly influenced by Eisenhardt (1989), Jensen and Meckling (1976), and Ross (1973), the conflict of interest and asymmetric information between principals and agents results in agency costs. In fact, precise information implies a better decision and thus higher benefit. Related to the agency theory, signaling theory focuses on the motives to overcome information asymmetries. A negative consequence of information asymmetry is adverse selection, which can be solved by signaling, for which 'trust' plays an important role (Akerlof, 1970; Healy \& Palepu, 2001). Signaling theory offers insights in the disclosure of advantageous information (Spence, 2002), which have a positive value for the corporation. All theories are based on the existence of information asymmetry and are concerned with the incentives to disclose the information. This also holds for voluntary strategy disclosure in the context of the relation from a corporation to its investors and other financial reporting addressees. Stakeholder theory offers convincing arguments for corporates to 
have a transparent communication to their audience, which is a variety of stakeholders. Based on a theoretical understanding, this study analyzes the determinants of the quality of voluntary strategy disclosure and is therefore related to other studies which focus on the impacts on (voluntary) disclosure levels in management reports or with respect to comparable parts of the financial reporting. The main research question of this study is as follows: What determines the quality of voluntary strategy disclosure in German management reports?

To answer this question, several hypotheses based on agency and stakeholder theory as well as on other research studies are formulated. Each of the hypotheses will be analyzed, which in sum shed light on the research question of this study.

Since the 1960s, a considerable body of research investigates the impact of corporate characteristics on voluntary disclosure level in financial reporting (see Ahmed \& Courtis, 1999; Cooke, 1989; Meek, Roberts, \& Gray, 1995; Singhvi \& Desai, 1971). The dominant method is to analyze information items expressed via explanatory variables on country-specific relevant disclosure scores. Disclosure scores are mostly calculated based on an unweighted or weighted scoring model, depending on the focus of the research. While most of research is done in the context of financial disclosure (Ferreira \& Rezende, 2007; Healy \& Palepu, 2001), only few studies focusing on voluntary strategy disclosure. The study from Ferreira and Rezende (2007) analyzed analytically the information disclosure about corporate strategy and pointed out that it provides strong incentives for partners of the firm to undertake strategy-specific investments. Especially the studies of Coebergh (2011) and Sieber (2011) are focusing on the determinants of voluntary strategy disclosure. The results of Coebergh (2011) showed that listing age, industry, dual-listing status, profitability and national ranking status have significant effects on voluntary disclosure of corporate strategy. Sieber (2011) showed that there is a significant relation between the independent variables company size, industry, leverage, indices classification, shared capital concentration and the dependent variable strategy disclosure. Both studies used different proxies for measuring the strategy disclosure and analyzed different determinants compared to this study. The study by Morris and Tronnes (2018) found that strategy disclosure is influenced by country-level characteristics and firm-level characteristics. Since an integrated reporting needs to contain strategic information and is forward-looking, strategy disclosure plays an important role in this reporting concept Ungerer (2013). Ungerer and Vorster (2015) found a positive relationship between integrated reporting and strategy disclosure.

Since several empirical and conceptual research models have already examined the determinants of voluntary disclosure and some of them are also in relation to voluntary strategy disclosure. This study focuses on determinants with a high theoretical foundation. The determinants of this study are primarily based on the theoretical concepts of agency theory, stakeholder theory and signaling theory. This study also includes two independent variables that have not been previously investigated in other studies in the context of voluntary strategy disclosure. As firm growth and capital intensity could be a decisive factor influencing the quality of voluntary strategy disclosure of a company in a theoretical context, the aim of this study is to analyze this relationship from an empirical perspective. We formulated the following hypotheses to analyze the research question of this study.

\subsection{Firm size}

Numerous studies found a significantly positive influence of firm size on disclosure (Abraham \& Tonks, 2006; Bushman, Piotroski, \& Smith, 2004; Camfferman \& Cooke, 2002; Chow \& WongBoren, 1987; Coebergh, 2011; Cooke, 1989; Lang \& Lundholm, 1993; Meek, Roberts, \& Gray, 1995; Prencipe, 2004; Sieber, 2011; Singhvi \& Desai, 1971). The majority of the studies found that more reporting is done by large companies compared to small companies - but different proxies were used (Ahmed \& Courtis, 1999). Especially for strategy disclosure a positive relation has been found by Sieber (2011). Furthermore, Hossain, Ahmed, and Godfrey (2005) found that there is a positive relation between firm size and prospective information disclosure. This provides strong support for the political and agency cost argument. In general, large companies have higher agency costs according to agency theory (Meek et al., 1995), because information asymmetries are more pronounced due to size and complexity of their business. 
Additional reporting can equalize this situation and save costs for the company. However, a large size implies that more stakeholders emerge who have a higher need for information. Based on the stakeholder theory, a large size implies more importance of the company and thus pressure from the stakeholder. Based on this argumentation, the following hypothesis $\mathrm{H} 1$ is set up:

\section{H1: Firm size has a positive effect on voluntary strategy disclosure quality.}

\subsection{Firm age}

The age of a company can be seen representative for the maturity or risk of the company (Bukh, Nielsen, Gormsen, \& Mouritsen, 2005) as well as the length of time a company has been listed on a capital market (Coebergh, 2011; Haniffa \& Cooke, 2002; Li, Pike, \& Haniffa, 2008), also the length since foundation may be relevant in explaining variability in the disclosure of information. Research indicates increased disclosure is positively associated with stock exchange listing status (Wallace, Naser, \& Mora, 1994), which contributes to the assumption that the length of time a company has been listed on a capital market has positive influence on disclosure. It is expected that this relationship also holds true for the length since foundation of the company. There are various arguments used to explain how firm age can determine the disclosure level of a company. On the one hand, firms which face higher uncertainty in their business have higher information asymmetries, which especially holds true for younger firms (Coebergh, 2011). Those firms can be expected to disclose more information than older companies according to the agency theory. However, according to stakeholder theory, older and younger companies can be expected to have stakeholders who are interested in relevant information. The age is not a proxy for importance of the company or public interest. For the reason that a positive as well as a negative relation between the lengths since the foundation of the firm and voluntary strategy disclosure can be expected, the hypothesis $H 2$ is drawn up:

H2: Firm age is related to voluntary strategy disclosure quality.

\subsection{Firm growth}

The firm growth of a company may have an impact on corporate strategy reporting. On the one hand, high growth companies may be particularly interested in communicating their successful strategy to investors. However, low-growth companies should also endeavor to change their situation by thinking about strategies for better growth and communicating long-term plans to stakeholders. This corresponds to the stakeholder theory, because increased disclosure and especially voluntary strategy disclosure may help investors and addressees of financial reporting to better understand the long-term goals of the company and growth opportunities in the future. Regarding agency theory, fast growing firms are getting more complex. This could lead to higher information asymmetries and non-transparent communication, why voluntary strategy disclosure could be used to lower the agency costs. Based on this argumentation, the positive effect outweighs the negative one and therefore hypothesis $\mathrm{H} 3$ can be formulated as follows:

H3: Firm growth of a company has a positive effect on voluntary strategy disclosure quality.

\subsection{Capital intensity}

Companies with a high level of property, plant and equipment are particularly long-term oriented and therefore tend to communicate their corporate strategy and strategic goals more strongly. Companies that have very little property, plant and equipment would tend to have high level of intangibles or short-term assets, which in turn also appears to require explanation and justification for relevant stakeholders. According to stakeholder theory, this higher level of disclosure is expected from stakeholders to understand the reasons for the high or low capital intensity of the company. More information in this context also reduces information asymmetries, which corresponds to agency theory and supports the expectation that there is a relation between capital intensity and voluntary strategy disclosure. Therefore, the following hypothesis $\mathrm{H} 4$ is formulated for the present research:

H4: The capital intensity of a company is related to voluntary strategy disclosure quality. 


\subsection{Leverage}

The capital structure is an important characteristic of a company and can influence its long-term preservation. In this context, the ratio of debt used to finance the assets of the firm is usually used as financial leverage. According to agency theory, agency costs of the firm increase with higher information requirements (Coebergh, 2011). Especially companies with higher leverage in the capital structure tend to have higher agency costs (Jensen \& Meckling, 1976). Therefore, it is assumed that there is an enhanced disclosure with increasing debt in order to counteract this effect. According to Ahmed and Courtis (1999), there is a positive relation between disclosure level and capitalization structures with higher proportions of fixed interest securities relative to equity. Francis, Khurana, and Pereira (2005) found that there is a higher voluntary disclosure level for firms with greater external financing needs. The study of Camfferman and Cooke (2002) from the Netherlands found that the debt-to-equity ratio is significantly positively associated with disclosure in annual reports. These results support the stakeholder theory, because the pressure for disclosure increases with higher interest of (external) stakeholders. Based on empirical studies, there are mixed results. Some studies found a negative relation between voluntary disclosure and leverage (Meek, Roberts, \& Gray, 1995) or no relation between these two aspects (Camfferman \& Cooke, 2002; Chow \& Wong-Boren, 1987; Gul \& Leung, 2004). Especially for strategy disclosure, Sieber (2011) found a positive relation with financial leverage. Based on the theoretical argumentation and prior empirical results, we expect that the positive effects outweigh the negative ones and we formulate the following hypothesis:

H5: Financial leverage of a company has a positive effect on voluntary strategy disclosure quality.

\subsection{Profitability}

According to stakeholder theory, there are several incentives of organizations to engage with stakeholders. Especially when a firm is successful, it would communicate this advantage to its stakeholders (Coebergh, 2011). Because there is cost as being perceived as a 'lemon', according to Akerlof (1970), which means that the company has only negative information. Agency theory and signaling theory play an important role in the explanation of the relationship between profitability and disclosure. Empirical evidence on the relation between firm profitability and disclosure is mixed. Whereas Gray, Meek, and Roberts (1995) and Meek, Roberts, and Gray (1995) found no evidence that voluntary disclosure behavior is different between more and less profitable firms. The study from Coebergh (2011) indicates that companies with an extensive strategy disclosure are less profitable. The hypothesis for this study is based on the theoretical argumentation and formulated as follows:

\section{H6: Profitability of a company has a positive ef- fect on voluntary strategy disclosure quality.}

\subsection{Ownership structure}

Based on the concept of agency theory, when a company has a high level of free float, there is a greater distance between the owners and the management. Compared to a concentrated shareholding, this leads to higher agency conflicts and, therefore, higher agency costs (Jensen \& Meckling, 1976). If ownership is concentrated in the hands of few dominant shareholders, they can also exert greater influence over company management and use internal information, which reduces agency costs. However, with a high level of free float, these costs could be reduced if information is voluntarily disclosed. The proportion of the free float in the shareholder structure thus appears to be a suitable determinant of corporate strategy reporting. Stakeholder theory suggests that the more influential stakeholders an organization has and the more the interests of these stakeholders differ, the higher is the need for additional information (Coebergh, 2011). Several studies confirm that outside ownership is positively associated with the level of disclosure (Patelli \& Prencipe, 2007). Based on the theoretical argumentation, we hypothesize as follows:

H7: Ownership structure of a company is related to voluntary strategy disclosure quality of a company. 


\section{METHODOLOGY}

\subsection{Sample}

This study focuses on 110 largest publicly listed German companies (based on market capitalization) between 2014 and 2018 of the main indices DAX, MDAX and TecDAX of the stock exchange provider Deutsche Börse Aktiengesellschaft. In total, the sample comprises 440 firm year observations. Following conventions, 22 foreign companies have to be excluded from the sample. They chose not to publish a management report according to German GAAP, because they were not registered under German law. Furthermore, one company has been excluded due to the fact that it has not published a management report at the due date June 30, 2018 of the study, because it was newly listed at the German stock exchange. As such, the final sample consists of 417 firm-year observations (see Table 1) ${ }^{1}$.

Table 1. Sample selection procedure

\begin{tabular}{|c|c|c|c|c|c|}
\hline $\begin{array}{c}\text { Sampling procedure } \\
\text { steps }\end{array}$ & $\begin{array}{c}\text { June } \\
30, \\
2015\end{array}$ & $\begin{array}{c}\text { June } \\
30, \\
2016\end{array}$ & $\begin{array}{c}\text { June } \\
30, \\
2017\end{array}$ & $\begin{array}{c}\text { June } \\
30, \\
2018\end{array}$ & Total \\
\hline \multicolumn{6}{|c|}{ Firms listed in three key selection indices } \\
\hline DAX & 30 & 30 & 30 & 30 & 120 \\
\hline MDAX & 50 & 50 & 50 & 50 & 200 \\
\hline TecDAX & 30 & 30 & 30 & 30 & 120 \\
\hline Total & 110 & 110 & 110 & 110 & 440 \\
\hline $\begin{array}{l}\text { Firms excluded from } \\
\text { sample because of } \\
\text { registration under non- } \\
\text { German law }\end{array}$ & -4 & -5 & -6 & -7 & -22 \\
\hline $\begin{array}{l}\text { Firms excluded from } \\
\text { sample because of not } \\
\text { published management } \\
\text { report }\end{array}$ & - & - & - & -1 & -1 \\
\hline Number of sample firms & 106 & 105 & 104 & 102 & 417 \\
\hline $\ln \%$ & 25.42 & 25.18 & 24.94 & 24.46 & 100.00 \\
\hline
\end{tabular}

In order to proxy the extents to which the analyzed firms disclose information about strategy, the management reports with the due date June 30 th have been assessed. We categorize the data from July 1, 2014 until June 30, 2015 to the year 2015 , as we do for the other years, respectively. We chose this due date because most companies have December 31st as reporting date and the distance to different reporting dates of companies is in this case minimized. This leads to SDScores for the years 2015 to 2018 . The analyzed independent variables are presented on the date December 31st, as this complies with balance sheet date of the most companies in the sample. Based on the final 417 firm-year observations, most firms belong to companies from the sector 'Industrial'. Only few companies are member of the industry sector 'Oil \& Gas'. The research question is focusing on a German setting for various reasons. As Germany is the largest economy in Europe and the fourth largest in the world (International Monetary Fund, 2018), voluntary strategy disclosure of German capital market-oriented companies seems to be a relevant topic for investors all over the world. The legal requirements of the GAS 20 represents a unique legal basis and the German management report is a regulatory part of the financial reporting, why the German setting differs from other countries and seems valuable to analyze. Therefore, integration into a broader sample selection such as a European one or an U.S. setting would lead to an inconsistency based on the legal requirements companies have to follow.

\subsection{Dependent variable}

SDScore is the Strategy Disclosure Score and the dependent variable in the model, which measures the quality of voluntary strategy disclosure. Based on a prior literature review regarding evaluation models to measure disclosure of companies (Botosan, 1997; Broberg, Torbjörn, \& Collin, 2010; Cooke, 1989; Gray, Meek, \& Roberts, 1995; Jones, 2007; Meek, Roberts, \& Gray, 1995), and regarding self-constructed scoring models which solely focus on strategy reporting (Coebergh, 2011; Padia, 2012; Santema, Hoekert, van de Rijt, \& van Oijen, 2005; Santema, \& van de Rijt, 2001; Sieber, 2011; Sieber, Weibenberger, Oberdörster, \& Baetge, 2014), we identified only few established measurement tools for strategy disclosure. The aim of this study is to combine legal requirements with the classical understanding of a strategic management process. Since the GAS 20 is a regulation, which has not been analyzed before in context of strategy disclosure, we constructed a new scoring model, which is not based on one from prior literature. Nevertheless, there are similarities to the scoring model from Sieber (2011), where the pro-

1 Companies with the legal form of a 'Societas Europaea' are included in the sample because in these cases the law of the state of residence must be applied. 
cess of the strategy management process played a major role. But the study of Sieber (2011) is based on an outdated legal setting and therefore focuses on other criteria. For the analysis of this study, a scoring model with fifteen elements has been selected, which in sum give a comprehensive and decision-relevant picture of the disclosure of corporate strategy (for details see Appendix A, Table A1). The categories of the scoring model are aligned with the steps of a classical strategic management process (Robbins \& Coulter, 2016; Welge \& Al-Laham, 2012), which consist of the strategic planning, strategy analysis, strategy formulation, strategy implementation and strategy control. The criteria relate to the corporate strategy and strategic objectives of the company on a corporate level, which excludes strategies on business unit level or in segment reporting. Furthermore, all criteria in the strategic context are analyzed based on the individual strategy and defined strategic objectives of the company. Hence, in a first step, the corporate strategy and strategic objectives for a company are defined and afterwards the criteria of the scoring model are evaluated individually for each company of the sample. This increases the validity of the scoring model and excludes that companies with inconsistent communication are evaluated positive. Therefore the SDScore measures the quality of reporting and not the extent.

The scoring model uses a similar approach to Sieber (2011) and the SDScore is calculated as follows:

$$
\begin{aligned}
& S D_{t, i}=\sum_{k=1}^{n} S_{t, k, i}, \\
& \text { SDScore }_{t, i}=\frac{S D_{t, i}}{S D^{\max }},
\end{aligned}
$$

where $s_{t, k, i}$ - disclosure of aspect $k$ of corporate $i$ in $t ;\{0 \vee 1\}, S D_{t, i}$ - strategy disclosure value of

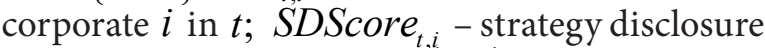
score of corporate $i$ in $t ;\{0,1\}, S D^{\max }-\max -$ imum possible number of strategy disclosures, where the subscript letters indicate the following: $t$ - year, $i$ - firm, $k$ - aspect of strategy disclosure. An unweighted summation adds the dichotomously distributed ratings for each company of the sample. The result presents the $S D_{t, i}$ (strategy disclosure value) for a specific corporate $i$. To calculate the SDScore, the ratio of the strategy dis- closure value and the maximum strategy disclosure value for the specific corporate will be calculated. The maximum strategy disclosure value is constant over the observation period and equal for all companies with 15 points. The SDScore is a continuous variable between 0 and 1 , whereas 1 represents a full disclosure and that information to all criteria are reported. Next, all values are transferred in a percentage scale to ease later interpretation of statistics and empirical results. The only study which uses a similar approach is Sieber (2011), whereas other studies like Santema and van de Rijt (2001) and Padia (2012) use nondichotomous scores and no categorization of the criteria.

\subsection{Independent variables}

In this study, firm size (SIZE) is used as independent variable. We use the firm's market value of equity which is the market capitalization at year-end. This approach is consistent with other studies such as Hope (2003) and Lee (2017). To represent the maturity and risk of the company, the firm age (AGE) is used as independent variable (Graham, Harvey, \& Rajgopal, 2005). The growth of a company (GROWTH) is measured by market-to-book value, which is the market value of the company's equity divided by the book value of the company's equity. It is thus a statement about the under- or overestimation of the firms equity and a sign of how cautious the management acts. Furthermore, potential growth is already priced in the market value, hence higher market capitalization, but not in the book value of the equity, why the market-tobook value can be seen as a suitable proxy for firm growth. The capital intensity (CAPIN) is another company-specific independent variable, which is measured by the ratio of total intangible assets and total assets of the firm. Similar to Chow and Wong-Boren (1987), we use the leverage of the company (LEV) expressed by the ratio of the book value of total liabilities divided by the book value of total assets to measure the capital structure of the company. To proxy for the profitability of the firm (PROF), we employ the variable EBITDA-Return on Assets. This is calculated as earnings before interests, taxes, depreciation and amortization divided by total assets. As a measurement of the ownership 
structure (OWNERST), the relative free float of a company is used. This is the percentage of total shares in issue available to ordinary investors, calculated as the total number of shares less the strategic holdings. The variable SIZE is scaled in billion euros and the AGE in years. All other independent variables are a ratio and therefore indicated as percent value.

\subsection{Control variables}

Because this study considers ten different industries, we control for unobserved differences among them. To represent industry membership of firms (INDUSTRY), we used dummy variables, which is consistent with most studies like Duran and Rodrigo (2018), Reverte (2009). We followed the Thomson Reuters Datastream classification based on the Industry Classification Benchmark. This leads to 10 industry membership groups: Consumer Goods (INDUSTRY1), Basic Materials (INDUSTRY2), Healthcare (INDUSTRY3), Consumer Services (INDUSTRY4), Industrials (INDUSTRY5), Utilities (INDUSTRY6), Financials (INDUSTRY7), Oil \& Gas (INDUSTRY8), Telecommunications (INDUSTRY9) and Technology (INDUSTRY10). We assigned a one if a firm belonged to a particular industry, and a zero if otherwise.

\section{MODEL}

In order to test the formulated hypotheses, we utilize a panel data model and a longitudinal regression analysis with random effects. Based on the Hausman test and Sargan-Hansen test, we decide to use a random effects model for the analysis instead of a fixed effects model. This allows controlling for unobserved heterogeneity across firms, because companies are studied across time. We construct an empirical model with the Strategy Disclosure Score (SDSCORE) as the dependent variable. As explanatory variables firm size (SIZE), firm age (AGE), firm growth (GROWTH), capital intensity (CAPIN), leverage (LEV), profitability (PROF) and ownership structure (OWNERST) are added. The variable INDUSTRY is added to control for industry-specific effects and shows the industry membership of the company. This yields the following regression equation:

$$
\begin{aligned}
& \text { SDScore }_{i, t}=\beta_{0}+\beta_{1} \operatorname{SIZE}_{i, t}+\beta_{2} A G E_{i, t}+ \\
& +\beta_{3} \text { GROWTH }_{i, t}+\beta_{4} \operatorname{CAPIN}_{i, t}+ \\
& +\beta_{5} \text { LEV }_{i, t}+\beta_{6} \text { PROF }_{i, t}+ \\
& +\beta_{7} \text { OWNERST }_{i, t}+\sum_{j=8}^{17} \beta_{j} \operatorname{INDUSTRY}_{i, t}+\varepsilon_{i, t},
\end{aligned}
$$

where the subscript letters indicate the following: $t$ - year, $i$ - firm, $j$ - industry. To avoid perfect multicollinearity in the model, we omitted one industry membership dummy variable. The multiple regression model is used to assess the extent to which variability in the voluntary strategy disclosure is explained by the previously hypothesized financial and non-financial firm-specific characteristics. To check for multicollinearity, the Person and Spearman correlation matrices are reviewed and variance inflation factors (VIF) are analyzed. Normality tests for the residuals are conducted based on skewness/kurtosis tests of normality as well as based on the Shapiro and Wilk (1965) and Shapiro-Francia normality tests. Furthermore, a histogram and Q-Q plot was conducted to test the normality assumption. Heteroscedasticity was analyzed by the Breusch Pagan/Cook-Weisberg test as well as by an analysis of the plots of residuals against predicted values. To test for the autocorrelation assumption, the Wooldridge test for autocorrelation is conducted in addition to an analysis of the plots of residuals against predicted values.

\section{RESULTS AND DISCUSSION}

\subsection{Descriptive statistics and bivariate results}

Table 2 shows the descriptive statistics of the sample with respect to the SDScore (SDSCORE), firm size (SIZE), firm age (AGE), growth (GROWTH), capital intensity (CAPIN), leverage (LEV), profitability (PROFIT) and ownership structure (OWNERST). The mean, minimum, maximum, percentiles, standard deviation values as well as number of observed companies are reported. The SDScore takes a maximum value of $100 \%$ and a minimum value of $0 \%$ over the observation period. The results show that the SDScore of the largest publicly listed German companies are moderate in all three years, as the mean is $47.68 \%$. These are similar results like Padia (2012), Santema and 
Table 2. Descriptive statistics of metric variables

\begin{tabular}{|c|c|c|c|c|c|c|c|c|c|}
\hline \multirow{2}{*}{ No. } & \multirow{2}{*}{ Variables } & \multirow{2}{*}{ Mean } & \multicolumn{2}{|c|}{ Extremes } & \multicolumn{3}{|c|}{ Percentiles } & \multirow{2}{*}{$\begin{array}{l}\text { Standard } \\
\text { deviation }\end{array}$} & \multirow{2}{*}{$\mathbf{N}$} \\
\hline & & & Min & Max & $25 \%$ & $50 \%$ & $75 \%$ & & \\
\hline 1 & SDSCORE & 47.68 & 0.00 & 100.00 & 40.00 & 46.66 & 53.33 & 15.17 & 417 \\
\hline 2 & SIZE & $14,210.58$ & 143.81 & $111,523.7$ & $1,977.47$ & $5,157.85$ & $13,235.08$ & $21,927.32$ & 417 \\
\hline 3 & $A G E$ & 71.97 & 1.00 & 191.00 & 21.00 & 50.00 & 127.00 & 53.34 & 417 \\
\hline 4 & GROWTH & 2.64 & -16.92 & 15.44 & 1.34 & 2.18 & 3.14 & 2.38 & 410 \\
\hline 5 & CAPIN & 23.08 & 0.00 & 94.01 & 5.28 & 17.33 & 37.97 & 20.24 & 417 \\
\hline 6 & LEV & 34.79 & 0.00 & 209.30 & 16.96 & 33.28 & 50.23 & 24.28 & 417 \\
\hline 7 & PROF & 11.16 & -15.50 & 77.80 & 7.67 & 11.36 & 14.03 & 7.75 & 415 \\
\hline 8 & OWNERST & 71.41 & 3.00 & 100.00 & 50.00 & 77.00 & 93.00 & 24.15 & 415 \\
\hline
\end{tabular}

Note: SDSCORE: Strategy Disclosure Score; SIZE: firm size in billion euros (market capitalization); AGE: firm age in years; GROWTH: market-to-book-value; CAPIN: capital intensity (intangibles/total assets); LEV: financial leverage (total liabilities/ total assets); PROFIT: profitability (EBITDA/total assets); OWNERST: ownership structure (relative free float).

Table 3. Pearson and spearman correlation matrix

\begin{tabular}{c|c|c|c|c|c|c|c|c|c}
\hline No. & Variables & $\mathbf{1}$ & $\mathbf{2}$ & $\mathbf{3}$ & $\mathbf{4}$ & $\mathbf{5}$ & $\mathbf{6}$ & $\mathbf{7}$ & $\mathbf{8}$ \\
\hline 1 & SDSCORE & 1 & $0.25^{* * *}$ & 0.01 & $0.18^{* * *}$ & $0.21^{* * *}$ & $0.09^{*}$ & $0.28^{* * *}$ & 0.03 \\
\hline 2 & SIZE & $0.29^{* * *}$ & 1 & $0.19^{* * *}$ & -0.07 & 0.01 & $0.30^{* * *}$ & -0.02 & 0.03 \\
3 & AGE & -0.04 & $0.24^{* * *}$ & 1 & -0.23 & $-0.13^{* * *}$ & 0.02 & $-0.10^{*}$ & $0.23^{* * *}$ \\
\hline 4 & GROWTH & $0.12^{* *}$ & $-0.09^{* *}$ & $-0.23^{* * *}$ & 1 & $0.42^{* * *}$ & $-0.16^{* * *}$ & $0.48^{* * *}$ & $-0.09^{*}$ \\
5 & CAPIN & $0.21^{* * *}$ & $0.11^{* *}$ & $-0.15^{* * *}$ & $0.24^{* * *}$ & 1 & 0.01 & $0.31^{* * *}$ & 0.01 \\
6 & LEV & 0.06 & $0.18^{* * *}$ & $0.09^{*}$ & $-0.21^{* * *}$ & 0.01 & 1 & $-0.21^{* * *}$ & $0.18^{* * *}$ \\
7 & PROF & $0.20^{* * *}$ & -0.03 & -0.07 & $0.38^{* * *}$ & $0.16^{* * *}$ & $-0.16^{* * *}$ & 1 & $-0.18^{* * *}$ \\
\hline 8 & OWNERST & 0.03 & $0.17^{* * *}$ & $0.23^{* * *}$ & $-0.14^{* * *}$ & 0.02 & $0.13^{* * *}$ & $-0.19^{*}$ & 1 \\
\hline
\end{tabular}

Note: $* p \leq 0.10, * * p \leq 0.05, * * * p \leq 0.01$, SDSCORE: Strategy Disclosure Score; SIZE: firm size in billion euros (market capitalization); AGE: firm age in years; GROWTH: market-to-book-value; CAPIN: capital intensity (intangibles/total assets); LEV: financial leverage (total liabilities/total assets); PROF: profitability (EBITDA/total assets); OWNERST: ownership structure (relative free float). The numbers below the diagonal represent Pearson correlation coefficients and those above the diagonal, Spearman rank correlation coefficients.

van de Rijt (2001), and Sieber (2011) found. In Table 3, the matrix shows Pearson and Spearman correlations. As expected, the strategy disclosure quality is increasing by size (SIZE), growth (GROWTH), capital intensity (CAPIN) and profitability (PROF) of the firm. Small-medium correlations (Cohen, 1988, p. 80, regarding Pearson correlation coefficients) are observed for the SDScore with GROWTH $(r=.12, p<.05)$, CAPIN $(r=.21$, $p<.01)$ and PROF $(r=.20, p<.01)$. In line with the respective hypothesis $H 1$, larger firms are more likely to have higher levels of SDScore, exhibiting a medium correlation of $r=.29(p<.01)$ for SIZE. For both parametric and nonparametric correlation measures, these relationships are significant and hence support the validity of the estimation as a measure of voluntary strategy disclosure quality. All other variables do not show any correlation with the SDScore. This bivariate analysis is based on the correlation matrix according to Pearson and to Spearman, both analyses provide similar results.

\subsection{Regression results}

In order to corroborate the hypotheses $\mathrm{H} 1-\mathrm{H} 8$, a multiple regression analysis is conducted. Despite the correlation among some variables, which can be seen in the correlation matrices (Table 3); all other basic assumptions for a regression analysis are not violated in the used statistical model. As described before, we performed tests whether excess multicollinearity is present in the models, we test for normality of the residuals, heteroscedasticity and autocorrelation, and find no violations. Table 4 shows the results from the multiple regression models, using a random effects model with the SDScore as dependent variable. The SDScore is significantly and positively associated with firm size (SIZE; $\beta_{1}=0.0002$ at $1 \%$ level). Furthermore, the same results are found in Model 2 if the control variables for industry membership (INDUSTRY) are added and robust standard errors are used (SIZE; $\beta_{1}=0.0002$ at $5 \%$ level). As expected in Hypothesis 1 (H1), there is a positive 
relation between the strategy disclosure quality of a firm and the firm size. Thus, Hypothesis 1 can be confirmed, which is consistent to results of prior empirical studies assessing the determinants of disclosure like Abraham and Tonks (2006), Agca and Önder (2007), Bushman, Piotroski, and Smith (2004), Camfferman and Cooke (2002), Meek, Roberts, and Gray (1995), Prencipe (2004), and Singhvi and Desai (1971). There is also a positive significant effect of firm growth (GROWTH) and capital intensity (CAPIN) on the strategy disclosure quality in Model 1 (GROWTH: $\beta_{3}=0.5195$ at $5 \%$ level; CAPIN: $\beta 4=0.0834$ at $5 \%$ level). For the Model 2 with robust standard errors and industry membership, only significance for firm growth can be found. Thus, a positive effect of firm growth and capital intensity can be observed, which confirms the hypotheses 3 (H3) and 4 (H4). No association is found for the independent variables firm age (AGE), financial leverage (LEV), profitability (PROF) and ownership structure (OWNERST).

The results thus support the theoretical assumption that voluntary strategy disclosure reduces information asymmetries according to agency theory, because these are more pronounced because of the size and complexity of the business and voluntary reporting can equalize this situation. Especially large companies mostly have an own department for strategy and strategy communication. The larger and more fast-growing a company is, the more pressure stakeholders exert on firms to provide relevant information to minimize information asymmetries and inform all stakeholders about important disclosure. Fast-growing companies are mostly active in a highly competitive environment and the strategy of the firm is important to defend their position. A high level of intangible assets could also lead to information asymmetries because of the nature of the asset, because it appears to require explanation and justification for relevant stakeholders. Companies with a high level of intangible assets mostly have a high need to explain their business and understanding how they want to generate value in the longterm. Therefore, the finding that capital intensity, which is measured by a high level of intangible assets, increases the quality of voluntary strategy disclosure, supports the assumption that information asymmetries can be reduced. Research studies, which also focused on determinants of strate- gy disclosure, found mixed results. Some empirical studies confirm the relation of firm size and disclosure (Ahmed \& Courtis, 1999; Cooke, 1989; Meek, Roberts, \& Gray, 1995; Morris \& Tronnes, 2018; Sieber, 2011). Especially the results of Sieber (2011) and Morris and Tronnes (2018) support this hypothesis for strategy disclosure. In contrast, the study of Coebergh (2011) did not confirm this relation. The findings for firm growth and capital intensity are new in academic literature and therefore a valuable new insight for management practice and a contribution to the research field of voluntary strategy disclosure. From a practical point of view, these results may be of interest for standard setting bodies and regulators when evaluating disclosure requirements.

\subsection{Robustness checks}

Table 5 presents the results of the first robustness check of regressions run separately for the years 2015 to 2018. These findings are consistent with the main results. This supports that firm size (SIZE) has in each year a positive significant effect on strategy disclosure quality (SDSCORE). Furthermore, growth of a firm shows a positive significant influence on the SDScore. The same holds true for capital intensity (CAPIN) in the years 2015 and 2016. A negative significant relationship between firm age (AGE) and the SDScore is found in the years 2017 and 2018. Profitability (PROF) seems to influence strategy disclosure significantly positive in the years 2017 and 2018. The robustness of the previous multiple regression analysis is thus shown by the first robustness check to control for time effects.

As a second robustness check, a multiple regression analysis with random effects (robust standard errors) with different proxies for firm size is conducted, as this is the explanatory variable with the highest significance in the previously conducted multiple regression model. In Model 3 we use the number of employees (SIZE1), in Model 4 the logarithm of the number of employees (SIZE2) and in Model 5 the book value of total assets (SIZE3) as proxies. As it is shown in Table 6, firm size is positively significant related to the SDScore in Model 3 and Model 4. The firm growth operationalized by the market-to-book-value influences the quality of strategy disclosure significantly posi- 
tive in all three models as well as capital intensity, which is measured by the ratio of intangibles to total assets. Furthermore, we calculated these models with the control variable INDUSTRY (see Table 7). For Model 6 we use the number of employees (SIZE1), in Model 7 the logarithm of the number of employees (SIZE2) and in Model 8 the book value of total assets (SIZE3) as proxies.
The results show that only Model 7 shows a significantly positive relation of size and voluntary strategy disclosure. This supports Hypothesis $\mathrm{H1}$ and the results from Model 2, which is the baseline model of this study. All robustness checks support the results of the main results from Table 4 and especially the significantly positive relation of firm size and SDScore.

Table 4. Results of multiple regression models

\begin{tabular}{|c|c|c|c|c|c|c|c|}
\hline \multirow{2}{*}{\multicolumn{2}{|c|}{$\begin{array}{c}\text { Dependent variable: SDSCORE } \\
\text { Explanatory variables }\end{array}$}} & \multicolumn{3}{|c|}{$\begin{array}{l}\text { Model } 1 \\
\text { with robust st. errors }\end{array}$} & \multicolumn{3}{|c|}{$\begin{array}{c}\text { Model } 2 \\
\text { with robust st. errors and industry } \\
\text { membership }\end{array}$} \\
\hline & & Coefficients & z-stat. & Sig. & Coefficients & z-stat. & Sig. \\
\hline \multirow{2}{*}{\multicolumn{2}{|c|}{ SIZE }} & $0.0002 * * *$ & \multirow{2}{*}{2.82} & \multirow{2}{*}{0.005} & $0.0002 * *$ & \multirow{2}{*}{2.35} & \multirow{2}{*}{0.019} \\
\hline & & $(0.0001)$ & & & $(0.0001)$ & & \\
\hline \multirow{2}{*}{\multicolumn{2}{|c|}{ AGE }} & -0.0188 & \multirow{2}{*}{-0.87} & \multirow{2}{*}{0.385} & -0.0370 & \multirow{2}{*}{-1.61} & \multirow{2}{*}{0.108} \\
\hline & & $(0.0217)$ & & & $(0.0231)$ & & \\
\hline \multirow{2}{*}{\multicolumn{2}{|c|}{ GROWTH }} & $0.5195^{* *}$ & \multirow{2}{*}{2.07} & \multirow{2}{*}{0.039} & $0.5201^{* *}$ & \multirow{2}{*}{1.97} & \multirow{2}{*}{0.049} \\
\hline & & $(0.2513)$ & & & $(0.2642)$ & & \\
\hline \multirow{2}{*}{\multicolumn{2}{|c|}{ CAPIN }} & $0.0834 * *$ & \multirow{2}{*}{2.15} & \multirow{2}{*}{0.032} & 0.0605 & \multirow{2}{*}{1.25} & \multirow{2}{*}{0.21} \\
\hline & & $(0.0388)$ & & & $(0.0483)$ & & \\
\hline & & 0.0032 & & & 0.0326 & & \\
\hline LEV & & $(0.0486)$ & 0.07 & $0.94 /$ & $(0.0522)$ & 0.62 & 0.532 \\
\hline & & 0.1460 & & & 0.0844 & & \\
\hline PRC & & $(0.0999)$ & 1.46 & 0.144 & $(0.0956)$ & 0.88 & $0.3 / 7$ \\
\hline & & 0.034 & & & 0.0209 & 048 & \\
\hline UV & INERSI & $(0.0392)$ & 0.81 & 0.386 & $(0.0438)$ & 0.48 & 0.633 \\
\hline & & & INDU & & & & \\
\hline & & - & - & - & 4.6534 & & \\
\hline 1 & Consumer goods & - & - & - & $(4.2056)$ & 1.11 & 0.269 \\
\hline & & & & & 4.5964 & & \\
\hline 2 & Basic materials & - & - & - & $(3.9522)$ & 1.16 & 0.245 \\
\hline & & & & & 2.7763 & & \\
\hline 3 & Healthcare & - & - & - & $(3.7968)$ & 0.13 & 0.465 \\
\hline 4 & Consumer services & - & - & - & -5.0136 & -117 & 0.243 \\
\hline 4 & consumer services & - & - & - & $(4.2906)$ & $-1.1 /$ & 0.243 \\
\hline & & & & & 2.4774 & & \\
\hline 5 & Industrials & - & - & - & $(3.5526)$ & 0.7 & 0.486 \\
\hline & & & & & -7.9756 & & \\
\hline 6 & Utilities & - & - & - & $(8.8350)$ & -0.9 & 0.367 \\
\hline 7 & Financials & _- & - & - & -3.5165 & -078 & 0433 \\
\hline I & Financlals & - & - & - & $(4.4853)$ & -0.18 & 0.433 \\
\hline & & & & & -2.3088 & & \\
\hline 8 & Oil \& Gas & - & - & - & (3.5604) & -0.65 & 0.517 \\
\hline 9 & & & & & 3.0283 & & \\
\hline 9 & Telecommunications & - & - & - & $(5.2020)$ & 0.58 & 0.56 \\
\hline & Technology & - & - & - & omitted & - & - \\
\hline 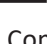 & astant & $38.8079 * * *$ & 113 & 0000 & $40.5847 * * *$ & 106 & 0000 \\
\hline Con & istant & $(3.4337)$ & 11.3 & 0.000 & $(3.8305)$ & 10.6 & 0.000 \\
\hline$R-\mathrm{s}$ & quared within & 0.0093 & - & - & 0.0099 & - & - \\
\hline$R$-s & quared between & 0.1764 & - & - & 0.2260 & - & - \\
\hline$R-\mathrm{s}$ & quared overall & 0.1500 & - & - & 0.1942 & - & - \\
\hline $\mathrm{Wa}$ & Id Chi Squared & $22.64 * * *$ & - & - & $38.73^{* * *}$ & - & - \\
\hline rho & & 0.5769 & - & - & 0.5845 & - & - \\
\hline Obs & servations & 408 & - & - & 408 & - & - \\
\hline
\end{tabular}

Note: $* p \leq 0.10, * * p \leq 0.05, * * * p \leq 0.01$, SDSCORE: Strategy Disclosure Score; SIZE: firm size in billion euros (market capitalization); AGE: firm age in years; GROWTH: market-to-book-value; CAPIN: capital intensity (intangibles/total assets); LEV: financial leverage (total liabilities/total assets); PROF: profitability (EBITDA/total assets); OWNERST: ownership structure (relative free float). Robust Standard Errors are in brackets. 
Table 5. Robustness check 1: regression models by year

\begin{tabular}{|c|c|c|c|c|c|c|c|c|}
\hline \multirow{2}{*}{$\begin{array}{l}\text { Dependent variable: SDSCORE } \\
\text { Explanatory variables }\end{array}$} & \multicolumn{2}{|c|}{$t=2015$} & \multicolumn{2}{|c|}{$t=2016$} & \multicolumn{2}{|c|}{$t=2017$} & \multicolumn{2}{|c|}{$t=2018$} \\
\hline & Coefficients & Sig. & Coefficients & Sig. & Coefficients & Sig. & Coefficients & Sig. \\
\hline \multirow{2}{*}{ SIZE } & $0.0002 * *$ & \multirow{2}{*}{0.032} & $0.0002^{* * *}$ & \multirow{2}{*}{0.001} & $0.0002^{* * *}$ & \multirow{2}{*}{0.006} & $0.0002 *$ & \multirow{2}{*}{0.086} \\
\hline & $(0.0001)$ & & $(0.0001)$ & & $(0.0001)$ & & $(0.0001)$ & \\
\hline \multirow[b]{2}{*}{ AGE } & 0.0132 & \multirow{2}{*}{0.595} & -0.0140 & \multirow{2}{*}{0.613} & $-0.0484^{*}$ & \multirow{2}{*}{0.093} & $-0.0778^{* *}$ & \multirow{2}{*}{0.016} \\
\hline & $(0.0249)$ & & $(0.0277)$ & & $(0.0286)$ & & $(0.0318)$ & \\
\hline \multirow{2}{*}{ GROWTH } & $1.3856^{* *}$ & \multirow{2}{*}{0.027} & -0.1655 & \multirow{2}{*}{0.813} & 0.4141 & \multirow{2}{*}{0.528} & $-0.7915 *$ & \multirow{2}{*}{0.078} \\
\hline & $(0.6171)$ & & $(0.6968)$ & & $(0.6530)$ & & $(0.4446)$ & \\
\hline \multirow{2}{*}{ CAPIN } & $0.1508^{* *}$ & \multirow{2}{*}{0.019} & $0.1414 * *$ & \multirow{2}{*}{0.012} & 0.0901 & \multirow{2}{*}{0.169} & -0.0140 & \multirow{2}{*}{0.792} \\
\hline & $(0.0630)$ & & $(0.0550)$ & & $(0.0650)$ & & $(0.0528)$ & \\
\hline \multirow{2}{*}{ LEV } & -0.0050 & \multirow{2}{*}{0.931} & 0.0282 & \multirow{2}{*}{0.647} & 0.1043 & \multirow{2}{*}{0.14} & 0.0344 & \multirow{2}{*}{0.639} \\
\hline & $(0.0576)$ & & $(0.0615)$ & & $(0.0700)$ & & $(0.0731)$ & \\
\hline \multirow{2}{*}{ PROF } & 0.0617 & \multirow{2}{*}{0.566} & 0.3525 & \multirow{2}{*}{0.115} & $0.4429 * *$ & \multirow{2}{*}{0.037} & $0.7708^{* * *}$ & \\
\hline & $(0.1071)$ & & $(0.2213)$ & & $(0.2095)$ & & $(0.1838)$ & 0.000 \\
\hline & 0.0085 & & 0.0026 & & 0.023 & & 0.0679 & \\
\hline OWNERST & $(0.0563)$ & 0.880 & $(0.0510)$ & 0.959 & $(0.0532)$ & 0.666 & $(0.0658)$ & 0.305 \\
\hline & $35.7613^{* * *}$ & 0.000 & $37.5779 * * *$ & 0.000 & $33.6348 * * *$ & 0.000 & $40.3422 * * *$ & 0.000 \\
\hline Constant & $(5.2915)$ & 0.000 & $(4.2320)$ & 0.000 & $(5.3169)$ & 0.000 & $(5.7787)$ & 0.000 \\
\hline$R$-squared & 0.1463 & - & 0.2301 & - & 0.2508 & - & 0.1904 & - \\
\hline$F$-statistic & $F(7,96)=2$ & $5 * *$ & $F(7,93)=4.1$ & $1 * * *$ & $F(7,94)=4.2$ & $6 * * *$ & $F(7,93)=3.8$ & $1 * * *$ \\
\hline Observations & 104 & - & 101 & - & 102 & - & 101 & - \\
\hline
\end{tabular}

Note: $* \leq 0.10, * * p \leq 0.05 ; * * * p \leq 0.01$, SDSCORE: Strategy Disclosure Score; SIZE: firm size in billion euros (market capitalization); AGE: firm age in years; GROWTH: market-to-book-value; CAPIN: capital intensity (intangibles/total assets); LEV: financial leverage (total liabilities/total assets); PROF: profitability (EBITDA/total assets); OWNERST: ownership structure (relative free float). All independent variables are measured separately for years 2015-2018 respectively. Robust standard errors are in brackets.

Table 6. Robustness check 2: regression models with different proxies for firm size without control variables

\begin{tabular}{|c|c|c|c|c|c|c|c|c|c|}
\hline \multirow{2}{*}{$\begin{array}{l}\text { Dependent variable: SDSCORE } \\
\text { Explanatory variables }\end{array}$} & \multicolumn{3}{|c|}{$\begin{array}{c}\text { Model } 3 \\
\text { with robust st. errors }\end{array}$} & \multicolumn{3}{|c|}{$\begin{array}{c}\text { Model } 4 \\
\text { with robust st. errors }\end{array}$} & \multicolumn{3}{|c|}{$\begin{array}{c}\text { Model } 5 \\
\text { with robust st. errors }\end{array}$} \\
\hline & Coefficients & z-stat & Sig. & Coefficients & z-stat & Sig. & Coefficients & z-stat & Sig. \\
\hline \multirow{2}{*}{ SIZE } & $0.0000^{* *}$ & \multirow{2}{*}{1.97} & \multirow{2}{*}{0.048} & $6.7576^{* * *}$ & \multirow{2}{*}{4.77} & \multirow{2}{*}{0.000} & 0.0000 & \multirow{2}{*}{0.52} & \multirow{2}{*}{0.602} \\
\hline & $(0.0000)$ & & & $(1.4156)$ & & & $(0.0000)$ & & \\
\hline \multirow{2}{*}{ AGE } & -0.0055 & \multirow{2}{*}{-0.24} & \multirow{2}{*}{0.807} & $-0.0461^{*}$ & \multirow{2}{*}{-1.87} & \multirow{2}{*}{0.061} & -0.0024 & \multirow{2}{*}{-0.1} & \multirow{2}{*}{0.917} \\
\hline & $(0.0226)$ & & & $(0.0247)$ & & & $(0.0228)$ & & \\
\hline \multirow{2}{*}{ GROWTH } & $0.5768^{* *}$ & \multirow{2}{*}{2.2} & \multirow{2}{*}{0.028} & $0.5882 * *$ & \multirow{2}{*}{2.53} & \multirow{2}{*}{0.011} & $0.5219 * *$ & \multirow{2}{*}{1.99} & \multirow{2}{*}{0.047} \\
\hline & $(0.2622)$ & & & $(0.2323)$ & & & $(0.2628)$ & & \\
\hline \multirow{2}{*}{ CAPIN } & $0.1042 * *$ & \multirow{2}{*}{2.32} & \multirow{2}{*}{0.02} & $0.0787^{*}$ & \multirow{2}{*}{1.84} & \multirow{2}{*}{0.066} & $0.1119^{* *}$ & \multirow{2}{*}{2.37} & \multirow{2}{*}{0.018} \\
\hline & $(0.0450)$ & & & $(0.0429)$ & & & $(0.0472)$ & & \\
\hline JFY & 0.0019 & 004 & 0.969 & -0.0175 & -0.42 & 0.677 & 0.0128 & 0.25 & 0.801 \\
\hline Lev & $(0.0475)$ & 0.04 & 0.905 & $(0.0421)$ & & & $(0.0510)$ & & \\
\hline & 0.1495 & & & 0.1288 & & & 0.1518 & & \\
\hline PROF & $(0.1013)$ & 1.48 & 0.14 & $(0.0992)$ & 1.3 & 0.194 & $(0.1046)$ & 1.45 & 0.146 \\
\hline & 0.0408 & & & $0.0683^{*}$ & & & 0.0440 & & \\
\hline OWNERSI & $(0.0392)$ & 1.04 & 0.299 & $(0.0370)$ & 1.85 & 0.065 & $(0.0400)$ & 1.1 & $0.2 / 2$ \\
\hline Constant & $37.9853^{* * *}$ & 1068 & מחمחת & $14.4656^{* * *}$ & 254 & 0011 & $38.2127 * * *$ & 1096 & 0.000 \\
\hline comstantit & $(3.5569)$ & 10.00 & 0.000 & $(5.6954)$ & 2.34 & 0.011 & $(3.4856)$ & 10.90 & 0.000 \\
\hline$R$-squared within & 0.0059 & - & - & 0.0149 & - & - & 0.0099 & - & - \\
\hline$R$-squared between & 0.1276 & - & - & 0.2223 & - & - & 0.0743 & - & - \\
\hline$R$-squared overall & 0.1005 & - & - & 0.1695 & - & - & 0.0662 & - & \\
\hline Wald Chi Squared & $18.29^{* *}$ & - & - & $42.56^{* * *}$ & - & - & $14.49 * *$ & - & - \\
\hline rho & 0.5958 & - & - & 0.5615 & - & - & 0.6202 & - & - \\
\hline Observations & 408 & - & - & 408 & - & - & 408 & - & - \\
\hline
\end{tabular}

Note: $* p \leq 0.10, * * p \leq 0.05, * * * p \leq 0.01$, SDSCORE: Strategy Disclosure Score; SIZE in Model 3: number of employees (SIZE1), SIZE in Model 4: logarithm of number of employees (SIZE2), SIZE in Model 5: book value of total assets (SIZE3); AGE: firm age in years; GROWTH: market-to-book-value; CAPIN: capital intensity (intangibles/total assets); LEV: financial leverage (total liabilities/total assets); PROF: profitability (EBITDA/total assets); OWNERST: ownership structure (relative free float). Robust standard errors are in brackets. 
Table 7. Robustness check 3: regression models with different proxies for firm size including control variables

\begin{tabular}{|c|c|c|c|c|c|c|c|c|c|c|}
\hline \multirow{2}{*}{\multicolumn{2}{|c|}{$\begin{array}{l}\text { Dependent variable: } \\
\text { SDSCORE } \\
\text { Explanatory variables }\end{array}$}} & \multicolumn{3}{|c|}{$\begin{array}{c}\text { Model } 6 \\
\text { with robust st. errors } \\
\text { and industry membership }\end{array}$} & \multicolumn{3}{|c|}{$\begin{array}{c}\text { Model } 7 \\
\text { with robust st. errors } \\
\text { and industry membership }\end{array}$} & \multicolumn{3}{|c|}{$\begin{array}{c}\text { Model } 8 \\
\text { with robust st. errors } \\
\text { and industry membership }\end{array}$} \\
\hline & & Coefficients & z-stat. & Sig. & Coefficients & z-stat. & Sig. & Coefficients & z-stat. & Sig. \\
\hline \multirow{2}{*}{\multicolumn{2}{|c|}{ SIZE }} & 0.0000 & \multirow{2}{*}{1.60} & \multirow{2}{*}{0.109} & $7.2810 * * *$ & \multirow{2}{*}{4.52} & \multirow{2}{*}{$\begin{array}{c}0.000 \\
(0.0000)\end{array}$} & 0.0000 & \multirow{2}{*}{0.98} & \multirow{2}{*}{0.329} \\
\hline & & $(0.0000)$ & & & $(1.6116)$ & & & $(0.000)$ & & \\
\hline \multirow{2}{*}{\multicolumn{2}{|c|}{ AGE }} & -0.0224 & \multirow{2}{*}{-0.94} & \multirow{2}{*}{0.349} & $-0.0624 * * *$ & \multirow{2}{*}{-2.66} & \multirow{2}{*}{0.008} & -0.0268 & \multirow{2}{*}{-1.14} & \multirow{2}{*}{0.256} \\
\hline & & $(0.0239)$ & & & $(0.0235)$ & & & $(0.0236)$ & & \\
\hline \multirow{2}{*}{\multicolumn{2}{|c|}{ GROWTH }} & $0.5918^{* *}$ & \multirow{2}{*}{2.20} & \multirow{2}{*}{0.028} & $0.6369 * * *$ & \multirow{2}{*}{2.69} & 0007 & $0.5278^{*}$ & 195 & 0051 \\
\hline & & $(0.2695)$ & & & $(0.2364)$ & & 0.007 & $(0.2707)$ & 1.95 & 0.051 \\
\hline$C A P$ & & $0.0877^{*}$ & 168 & (2092 & 0.0675 & 139 & 0166 & $0.0896^{*}$ & 168 & 0093 \\
\hline (2) & & $(0.0520)$ & 1.00 & 0.052 & $(0.0488)$ & 1.55 & 0.100 & $(0.0533)$ & 1.68 & 0.093 \\
\hline & & 0.0282 & & & 0.0033 & 0.08 & 0.939 & 0.0364 & 0.71 & 0.480 \\
\hline LEV & & $(0.0500)$ & 0.56 & 0.574 & $(0.0433)$ & 0.08 & 0.939 & $(0.0516)$ & 0.11 & 0.480 \\
\hline$P R O$ & & 0.0955 & 0.97 & 0.332 & 0.0944 & 0.96 & 0.336 & 0.0911 & 0.92 & 0.359 \\
\hline rno & & $(0.0985)$ & 0.91 & 0.332 & $(0.0982)$ & 0.90 & $(0.0994)$ & $(0.09994)$ & 0.92 & 0.359 \\
\hline & INERST & 0.0273 & 063 & 0.529 & 0.0444 & 1.07 & 0.283 & 0.0315 & 0.71 & 0.476 \\
\hline & INERDI & $(0.4333)$ & 0.03 & 0.529 & $(0.0413)$ & & $(0.0442)$ & $(0.0442)$ & & \\
\hline & & & & & DUSTRY & & & & & \\
\hline & Consumer goods & 5.4363 & 1.25 & 0.211 & 2.4206 & 0.60 & 0.548 & $7.5278 *$ & 183 & 0.067 \\
\hline 1 & Consumer goods & $(4.3490)$ & $1 . \angle 3$ & 0.211 & $(4.0316)$ & 0.00 & 0.348 & $(4.1032)$ & 1.83 & 0.061 \\
\hline 2 & Basic materials & 4.899 & 114 & 0256 & 2.3680 & 0.57 & 0.569 & 5.3553 & 122 & 0221 \\
\hline 2 & basic materials & $(4.3111)$ & 1.14 & 0.250 & $(4.1593)$ & 0.31 & 0.309 & $(4.3800)$ & 1.22 & $0.2 \angle 1$ \\
\hline & Healthcare & 2.7950 & 0.63 & 0.526 & 2.8210 & 0.66 & 0.507 & 3.5469 & 0.81 & 0.421 \\
\hline 3 & Healthcare & $(4.4040)$ & 0.03 & $0.5<0$ & $(4.2546)$ & 0.00 & 0.501 & $(4.4030)$ & 0.81 & 0.421 \\
\hline 4 & Consumer services & -5.8561 & -133 & 0183 & $-9.0586 * *$ & -210 & 0.036 & -5.1094 & $-1,14$ & 0.256 \\
\hline 4 & Consumer services & (4.3954) & -1.33 & 0.183 & $(4.3086)$ & -2.10 & 0.030 & $(4.4948)$ & -1.14 & $0 . \angle 50$ \\
\hline 5 & & 1.1771 & 0.30 & 0762 & -0.3683 & -010 & 0.919 & 2.3925 & 062 & 0.537 \\
\hline 5 & Inaustrlals & $(3.8788)$ & 0.30 & 0.102 & $(3.6200)$ & -0.10 & 0.919 & $(3.8773)$ & 0.62 & 0.531 \\
\hline 6 & Utilities & -6.9430 & -075 & 0451 & -12.1963 & -1.40 & 0.160 & -6.8078 & -0.73 & 0.466 \\
\hline 0 & vinties & $(9.2080)$ & -0.13 & 0.451 & $(8.6822)$ & -1.40 & 0.100 & (9.3309) & -0.13 & 0.400 \\
\hline 7 & & -2.0115 & -0.44 & 0.656 & 0.0530 & & 0.991 & -3.6027 & & \\
\hline 1 & Financials & $(4.5215)$ & -0.44 & 0.656 & $(4.4622)$ & 0.01 & 0.991 & $(4.6632)$ & -0.17 & 0.440 \\
\hline 8 & Oil \& Gas & -2.5976 & -067 & 0.504 & -3.0783 & -0.94 & 0.350 & -2.8319 & -0.71 & 0.476 \\
\hline 0 & $011 \times$ Uds & $(3.8845)$ & -0.01 & 0.304 & $(3.2922)$ & -0.94 & 0.350 & (3.9719) & -0.11 & 0.470 \\
\hline 9 & & 4.5153 & 067 & 505 & 2.6972 & & 0.591 & 5.1962 & & \\
\hline 9 & Ielecommunications & $(6.769)$ & $0.6 /$ & 0.505 & $(5.0216)$ & 0.54 & 0.591 & $(7.5765)$ & 0.69 & 0.493 \\
\hline 10 & Technology & omitted & - & - & omitted & - & - & omitted & - & - \\
\hline & & $39.5848 * * *$ & & 0.000 & $15.3658 * *$ & 2.36 & 0.018 & $39.6707 * * *$ & 9.79 & 0.000 \\
\hline & istant & $(3.9905)$ & 9.92 & 0.000 & $(6.5182)$ & 2.30 & 0.018 & $(4.0512)$ & 9.19 & 0.000 \\
\hline$R-\mathrm{sc}$ & quared within & 0.0067 & - & - & 0.0159 & - & - & 0.0122 & - & - \\
\hline$R-\mathrm{sc}$ & quared between & 0.1806 & - & - & 0.2951 & - & - & 0.1473 & - & - \\
\hline$R$-sc & quared overall & 0.1447 & - & - & 0.2233 & - & - & 0.1261 & - & - \\
\hline Wal & Id Chi Squared & $38.18^{* * *}$ & - & - & $68.80^{* * *}$ & - & - & $32.10 * * *$ & - & - \\
\hline rho & & 0.6026 & - & - & 0.5569 & - & - & 0.6218 & - & - \\
\hline Obs & servations & 408 & - & - & 408 & - & - & 408 & - & - \\
\hline
\end{tabular}

Note: $* p \leq 0.10, * * p \leq 0.05, * * * p \leq 0.01$, SDSCORE: Strategy Disclosure Score; SIZE in Model 6: number of employees (SIZE1), SIZE in Model 7: logarithm of number of employees (SIZE2), SIZE in Model 8: book value of total assets (SIZE3). All other variables are as defined in Table 4. Robust standard errors are in brackets. 


\section{CONCLUSION}

Voluntary strategy disclosure of firms is a widely neglected topic in theoretical and empirical research, but of high interest of investors and addressees of financial reporting. The determinants influencing the quality of voluntary strategy disclosure are largely under-researched, that's why this study has the aim to close a research gap. This study contributes to this relatively new stream of empirical disclosure research. Therefore, this topic is of considerable interest for decision-makers in both economic theory as well as in managerial practice. Our findings shed light on this matter, examining determinants of the quality of voluntary strategy disclosures made by a sample of 417 firm year observations of the largest listed German capital market-oriented companies drawn from a diverse range of industrial sectors. This study includes two variables, firm growth and capital intensity, which have not been analyzed before in the context of voluntary strategy disclosure, which give new insights in the characteristics of firms which tend to have a high quality of voluntary strategy disclosure. Furthermore, a self-constructed scoring model has been used which combines legal requirements and a theoretical understanding of the strategic management process. The unique aspect of the measurement tool that all criteria are individual evaluated for each company based on their corporate strategy and strategic objective differentiates this study from others. Findings show that the quality of voluntary strategy disclosure is significant positively influenced by firm size, firm growth and capital intensity. The results from this empirical research remain stable throughout a number of robustness checks. Based on the findings small companies, slow growing companies or with a low level of intangible assets are reluctant to disclose information about their corporate strategy and strategic objectives. The findings for the influence of firm size on disclosure is consistent with other empirical studies like Sieber (2011) and Morris and Tronnes (2018). The relation of firm growth and capital intensity on disclosure, especially strategy disclosure, is to the best of our knowledge not researched before and is therefore a valuable contribution to the research field. Based on the findings it can be understand which types of companies have a high quality of strategy disclosure. This may be of interest for standard setting bodies and regulators as well as financial reporting addressees to evaluate given information about corporate strategy and strategic objectives.

For the final appraisal of the study results, it is important to consider that the significance of the results is restricted by the inherent limitations of the study. The three main limitations are the analyzed determinants, the sample and the measurement tool of voluntary strategy disclosure. Other determinants which influence the disclosure quality of strategy related information are also conceivable and could be tested empirically. Furthermore, future research should aim to increase the number of companies in the sample to get a wider picture. This study focuses on a German sample. Future empirical analysis could use other European as well as international samples to identify differences in the disclosure quality based on the assumption, that different cultures, business environments and legal systems influence the level of strategy disclosure like Morris and Tronnes (2018). The time horizon could be increased to get new findings how relevant voluntary strategy disclosure is under different economic conditions. To understand differences between capital market-oriented companies and non-capital market-oriented companies, the sample in future research could comprise both company types. This study is based on disclosure in the management report, other sources are also used by the addressees (Ferreira \& Rezende, 2007) and can be further studied. Furthermore, the criteria used in the analysis are based on the theoretical strategic management process and on legal requirements for strategy disclosure in German management reports. Future studies could further extent or alternate this measurement of strategy disclosure. Despite basing the scoring model on the above mentioned theoretical and quasi-legal conceptualizations, it remains based on simplifications and on subjective assessment. Due to signaling theory, effects of strategy disclosure on the capital market performance of a firm could be analyzed in further research like the study of Sieber, Weibenberger, Oberdörster, and Baetge (2014) did. Future research could examine whether strategy disclosure in firms' management reports reduces the information asymmetry component of cost of capital. This might provide information if voluntary strategy disclosure is a relevant source of information for investors. 


\section{ACKNOWLEDGMENT}

The authors are grateful to the participants of the 42nd Annual Congress of the European Accounting Association in Paphos, Cyprus (2019), the HHL Graduate School of Management Colloquium for their constructive comments as well as the commentators of the Annual Conference of the European Academy of Management 2019 for their valuable input.

\section{REFERENCES}

1. Abraham, S., \& Tonks, I. (2006). Voluntary Corporate Disclosures by UK Companies (Unpublished manuscript). University of Exeter, UK. Retrieved from https:// pdfs.semanticscholar.org/e0a9/ f0d509e6f8a5f2f40891d95d3749fa113630.pdf

2. Agca, A., \& Önder, S. (2007). Voluntary Disclosure in Turkey: A Study on Firms Listed in Istanbul Stock Exchange (ISE). Problems and Perspectives in Management, 5(3), 241-251. Retrieved from https://www.researchgate.net/ publication/291286901_Voluntary_Disclosure_In_Turkey_A_ Study_On_Firms_Listed_In_Istanbul_Stock_Exchange_ISE

3. Ahmed, K. K., \& Courtis, J. K. (1999). Associations between corporate characteristics and disclosure levels in annual reports: a meta-analysis. The British Accounting Review, 31(1), 35-61. https://doi.org/10.1006/ bare. 1998.0082

4. Akerlof, G. A. (1970). The market for "lemons": quality uncertainty and the market mechanism. Quarterly Journal of Economics, 84, 488-500. https://doi.org/10.1016/ B978-0-12-214850-7.50022-X

5. Botosan, C. A. (1997). Disclosure level and the cost of equity capital. The Accounting Review, 72(3), 323-349. Retrieved from https://www.jstor.org/ stable/248475?seq=1\#page_scan_ tab_contents

6. Broberg, P., Torbjörn, T., \& Collin, S.-O. (2010). What explains variation in voluntary disclosure? A study of the annual reports of corporations listed on the Stockholm Stock Exchange. Journal of Management and Governance, 14(4),
351-377. Retrieved from https:// link.springer.com/article/10.1007/ s10997-009-9104-y

7. Bukh, N. P., Nielsen, C., Gormsen, P., \& Mouritsen, J. (2005). Disclosure of information on intellectual capital in Danish IPO prospectuses. Accounting, Auditing \& Accountability Journal, 18(6), 713-732. https://doi. org/10.1108/09513570510627685

8. Bushman, R. M., Piotroski, J. D., \& Smith, A. J. (2004). What Determines Corporate Transparency? Journal of Accounting Research, 42(2), 207-252. https://doi.org/10.1111/j.1475679X.2004.00136.x

9. Camfferman, K., \& Cooke, T. E. (2002). An Analysis of Disclosure in the Annual Reports of U.K. and Dutch Companies. Journal of International Accounting Research, 1(1), 3-30. http://dx.doi. org/10.2308/jiar.2002.1.1.3

10. Chow, C. W., \& Wong-Boren, A. (1987). Voluntary Financial Disclosure by Mexican Corporations. The Accounting Review, 62(3), 533-541. Retrieved from https:// www.jstor.org/stable/pdf/247575. pdf?seq=1\#page_scan_tab_contents

11. Coebergh, H. (2011). Voluntary disclosure of corporate strategy: Determinants and outcomes. An empirical study into the risks and payoffs of communicating corporate strategy (Doctoral dissertation). Retrieved from https://bradscholars.brad.ac.uk/

12. Cohen, J. (1988). Statistical Power Analysis for the Behavioral Sciences (2nd ed.). New York, Lawrence Erlbaum Associates.

13. Cooke, T. E. (1989). Voluntary Corporate Disclosure by Swedish
Companies. Journal of International Financial Management \& Accounting, 1(2), 171-195. https:// doi.org/10.1111/j.1467-646X.1989. tb00009.x

14. D’Amico, E., Coluccia, D., Fontana, S., \& Solimene, S. (2016). Factors Influencing Corporate Environmental Disclosure. Business Strategy and the Environment, 25(3), 178-192. https://doi.org/10.1002/ bse. 1865

15. Duran, I., \& Rodrigo, P. (2018). Why Do Firms in Emerging Markets Report? A Stakeholder Theory Approach to Study the Determinants of Non-Financial Disclosure in Latin America. Sustainability, 10(9), 3111. Retrieved from https://www.mdpi. com/2071-1050/10/9/3111/pdf

16. Eisenhardt, K. M. (1989). Agency Theory: An Assessment and Review. Academy of Management Review, 14(1), 57-74. Retrieved from https://www.jstor.org/ stable/258191?seq=1\#metadata info_tab_contents

17. Ferreira, D. \& Rezende, M. (2007). Corporate strategy and information disclosure. RAND Journal of Economics, 38(1), 164-184. Retrieved from https://www.jstor. org/stable/25046298?seq=1\#page_ scan_tab_contents

18. Francis, J. R., Khurana, I. K., \& Pereira, R. (2005). Disclosure Incentives and Effects on Cost of Capital around the World. The Accounting Review, 80(4), 1125-1162. Retrieved from https://www.jstor. org/stable/4093119? seq=1\#page_ scan_tab_contents

19. Graham, J. R., Harvey, C. R., \& Rajgopal, S. (2005). The economic implications of corporate financial reporting. Journal of Accounting 
and Economics, 40(1-3), 3-73. https://doi.org/10.1016/j.jacceco.2005.01.002

20. Gray, S. J., Meek, G. K., \& Roberts, C. B. (1995). International Capital Market Pressures and Voluntary Annual Report Disclosures by U.S. and U.K. Multinationals. Journal of International Financial Management \& Accounting, 6(1), 43-68. https://doi.org/10.1111/j.1467646X.1995.tb00049.x

21. Gul, F. A., \& Leung, S. (2004). Board leadership, outside directors' expertise and voluntary corporate disclosures. Journal of Accounting and Public Policy, 23(5), 351-379. https://doi.org/10.1016/j. jaccpubpol.2004.07.001

22. Haniffa, R. M., \& Cooke, T. E. (2002). Culture, Corporate Governance and Disclosure in Malaysian Corporations. $A B A-$ CUS, 38(3), 317-349. https://doi org/10.1111/1467-6281.00112

23. Hashim, M. H., Nawawi, A., \& Salin, A. S. A. P. (2014). Determinants of strategic information disclosure - Malaysian evidence. International Journal of Business and Society, 15(3), 547-572. Retrieved from https://www.researchgate. net/publication/273062913_Determinants_of_strategic_information_disclosure-Malaysian_evidence

24. Healy, P. M., \& Palepu, K. G. (2001). Information Asymmetry, Corporate Disclosure and the Capital Markets: A Review of the Empirical Disclosure Literature. Journal of Accounting and Economics, 31(1-3), 405-440. https://doi.org/10.1016/S01654101(01)00018-0

25. Hope, O.-K. (2003). Disclosure Practices, Enforcement of Accounting Standards and Analysts' Forecast Accuracy: An International Study. Journal of Accounting Research, 41(2), 235-272. https:// doi.org/10.1111/1475-679X.00102

26. Hossain, M., Ahmed, K., \& Godfrey, J. M. (2005). Investment Opportunity Set and Voluntary Disclosure of Prospective Information: A Simultaneous Equations Approach. Journal of Business Finance \& Accounting, 32(5-6),
871-907. https://doi.org/10.1111/ j.0306-686X.2005.00616.x

27. International Monetary Fund (2018). World Economic Outlook: Challenges to Steady Growth. Retrieved from https://www.imf. org/en/Publications/WEO/Issues/2018/09/24/world-economicoutlook-october-2018

28. Jensen, M. C., \& Meckling, W. H. (1976). Theory of the firm: Managerial behavior, agency costs and ownership structure. Journal of Financial Economics, 3(4), 305360. https://doi.org/10.1016/0304405X(76)90026-X

29. Jones, D. A. (2007). Voluntary disclosure in $\mathrm{R} \& \mathrm{D}$-intensive industries. Contemporary Accounting Research, 24(2), 489-522. Retrieved from https://papers.ssrn. $\mathrm{com} / \mathrm{sol} 3 /$ papers.cfm?abstract_ $\mathrm{id}=962368$

30. Lang, M., \& Lundholm, R. (1993). Cross-Sectional Determinants of Analyst Ratings of Corporate Disclosures. Journal of Accounting Research, 31(2), 246-271. Retrieved from https://www.jstor. org/stable/2491273?seq=1\#page scan_tab_contents

31. Lee, K.-H. (2017). Does Size Matter? Evaluating Corporate Environmental Disclosure in the Australian Mining and Metal Industry: A Combined Approach of Quantity and Quality Measurement. Business Strategy and the Environment, 26(2), 209-223. https://doi.org/10.1002/bse.1910

32. Li, J., Pike, R., \& Haniffa, R. (2008). Intellectual capital disclosure and corporate governance structure in UK firms. Accounting and Business Research, 38(2), 137-159. https:// doi.org/10.1080/00014788.2008.9 663326

33. Meek, G. K., Roberts, C. B., \& Gray, S. J. (1995). Factors influencing voluntary annual report disclosures by U.S., U.K. and continental multinational corporations. Journal of International Business Studies, 26(3), 555-572. Retrieved from https://www.jstor. org/stable/155561?seq=1\#page_ scan_tab_contents

34. Morris, R. D., \& Tronnes, P. C. (2018). The determinants of voluntary strategy disclosure: an international comparison. Accounting Research Journal, 31(3), 423-441. https://doi.org/10.1108/ ARJ-10-2015-0126

35. Padia, N. (2012). Disclosure of non-financial information on strategy in South African annual reports. African Journal of Business Management, 6(46), 11472 11479. https://doi.org/10.5897/ AJBM12.918

36. Patelli, L., \& Prencipe, A. (2007). The Relationship between Voluntary Disclosure and Independent Directors in the Presence of a Dominant Shareholder. European Accounting Review, 16(1), 5-33. https://doi. org/10.1080/09638180701265820

37. Porter, M. E. (1980). Competitive Strategy. New York, US. The Free Press.

38. Porter, M. E. (1997). Creating Tomorrow's Advantages. In Rowan Gibson (Ed.), Rethinking the Future: Rethinking business, principles, competition, control \& complexity, leadership, markets and the world (pp. 267-274). London, England. Nicholas Brealy Publishing.

39. Prencipe, A. (2004). Proprietary costs and determinants of voluntary segment disclosure: evidence from Italian listed companies. $\mathrm{Eu}$ ropean Accounting Review, 13(2), 319-340. https://doi.org/10.1080/0 963818042000204742

40. Reverte, C. (2009). Determinants of Corporate Social Responsibility Disclosure Ratings by Spanish Listed Firms. Journal of Business Ethics, 88(2), 351-366. Retrieved from https://link.springer.com/article/10.1007/s10551-008-9968-9

41. Robbins, S. P., \& Coulter, M. (2016). Management (13th ed.). Harlow, England.

42. Ross, S. A. (1973). The Economic Theory of Agency: The Principal's Problem. The American Economic Review, 63(2), 134-139. Retrieved from https://www.jstor.org/ stable/1817064?seq=1\#page_scan_ tab_contents

43. Santema, S., \& van de Rijt, J. (2001). Strategy Disclosure in Dutch Annual Reports. Euro- 
pean Management Journal, 19(1), 101-108. Retrieved from https:// ideas.repec.org/a/eee/eurman/ v19y2001ilp101-108.html

44. Santema, S., Hoekert, M., van de Rijt, J., \& van Oijen, A. (2005) Strategy disclosure in annual reports across Europe: a study on differences between five countries. European Business Review, 17(4), 352-366. https://doi. org/10.1108/09555340510607398

45. Shapiro, S. S. \& Wilk, M. B. (1965). An Analysis of Variance Test for Normality (Complete Samples). Biometrika, 52(3/4), 591-611. Retrieved from https://www.jstor. org/stable/2333709?seq=1\#page_ scan_tab_contents

46. Sieber, T. (2011). Strategieorientierte Berichterstattung im Lagebericht. Eine empirische Untersuchung börsennotierter Unternehmen in Deutschland (Doctoral dissertation). Frankfurt am Main, Germany. Peter Lang $\mathrm{GmbH}$.
47. Sieber, T., Weibenberger, B. A., Oberdörster, T., \& Baetge, J. (2014). Let's talk strategy: the impact of voluntary strategy disclosure on the cost of equity capital. Business Research, 7(2), 263-312. Retrieved from https://link.springer.com/ article/10.1007/s40685-014-0010-Z

48. Singhvi, S. S., \& Desai, H. B. (1971). An Empirical Analysis of the Quality of Corporate Financial Disclosure. The Accounting Review, 46(1), 129-138. Retrieved from https://www.jstor.org/ stable/243894?seq=1\#page_scan_ tab_contents

49. Spence, M. (2002). Signaling in Retrospect and the Informational Structure of Markets. The American Economic Review, 92(3), 434-459. Retrieved from https://www.jstor. org/stable/3083350?seq=1\#page_ scan_tab_contents

50. Ungerer, M., \& Vorster, S. (2015). Strategy disclosure reporting trends in South Africa: A 2010-2011 comparative analysis for six industry clusters. Southern African Business Review, 19(3), 78101. Retrieved from https://www. ajol.info/index.php/sabr/article/ view/127494

51. Ungerer, M. (2013). A comparative analysis of strategy disclosure reporting trends in South Africa in 2010. Southern African Business Review, 17(3), 27-56. Retrieved from https://www.ajol.info/index. php/sabr/article/view/110925

52. Wallace, O. R. S., Naser, K., \& Mora, A. (1994). The Relationship Between the Comprehensiveness of Corporate Annual Reports and Firm Characteristics in Spain. Accounting and Business Research, 25(97), 41-53. https://doi.org/10.10 80/00014788.1994.9729927

53. Welge, M. K., \& Al-Laham, A. (2012). Strategisches Management. Grundlagen - Prozess - Implementierung (6th ed.). Wiesbaden, Germany. Retrieved from https://www.springer.com/de/ book/9783658106478

\section{APPENDIX A}

Table A1. Data collection instrument

\begin{tabular}{|c|c|c|c|}
\hline Strategy phase & Sub-category & No. & Description of evaluation criteria \\
\hline \multirow{4}{*}{ Strategy analysis } & \multirow{2}{*}{$\begin{array}{l}\text { Economic } \\
\text { environment }\end{array}$} & 1. & Explanation of the business development in the context of the strategy \\
\hline & & 2. & Explanation of the economic situation in the context of the strategy \\
\hline & \multirow[b]{2}{*}{ Strategic situation } & 3. & Assessment of the expected business development in the context of the strategy \\
\hline & & 4. & $\begin{array}{l}\text { Assessment of the opportunities and risks of the company in the context of the } \\
\text { strategy }\end{array}$ \\
\hline \multirow{4}{*}{$\begin{array}{l}\text { Strategy } \\
\text { formulation }\end{array}$} & \multirow{3}{*}{ Strategic objectives } & 5. & Naming the strategic objective \\
\hline & & 6. & Extent of the strategic objectives \\
\hline & & 7. & Time reference of the strategic objectives \\
\hline & Corporate strategy & 8. & Naming the corporate strategy \\
\hline \multirow{2}{*}{$\begin{array}{l}\text { Strategy } \\
\text { implementation }\end{array}$} & \multirow{2}{*}{$\begin{array}{l}\text { Implementation } \\
\text { process }\end{array}$} & 9. & Explanation of the relevance of strategy in the management compensation system \\
\hline & & 10. & Explanation of the integration of strategy in internal control system \\
\hline \multirow{5}{*}{ Strategy control } & \multirow{4}{*}{ Changes in strategy } & 11. & Significant changes in strategic objectives compared to the previous year \\
\hline & & 12. & $\begin{array}{l}\text { Explanation of significant changes in strategic objectives compared to the previous } \\
\text { year }\end{array}$ \\
\hline & & 13. & Significant changes in corporate strategy compared to the previous year \\
\hline & & 14. & $\begin{array}{l}\text { Explanation of significant changes in corporate strategy compared to the previous } \\
\text { year }\end{array}$ \\
\hline & $\begin{array}{l}\text { Achievement of } \\
\text { strategic objectives }\end{array}$ & 15. & Statement on the state of achievement of strategic objectives \\
\hline
\end{tabular}

